\title{
PENGARUH KECEMASAN MATEMATIKA TERHADAP KEMAMPUAN PEMECAHAN MASALAH SISWA DI SMA
}

\section{(THE EFFECT OF MATHEMATICAL ANXIETY OF STUDENTS 'PROBLEM SOLVING ABILITY IN HIGH SCHOOL)}

\author{
Fajar Riski ${ }^{1}$, Indiana Marethi ${ }^{2}$, Isna Rafianti ${ }^{3}$ \\ ${ }^{1}$ Universitas Sultan Ageng Tirtayasa, Fajariski27@gmail.com \\ ${ }^{2}$ Universitas Sultan Ageng Tirtayasa, indianamarethi@untirta.ac.id \\ ${ }^{3}$ Universitas Sultan Ageng Tirtayasa, isnarafianti@untirta.ac.id
}

\begin{abstract}
Abstrak
Penelitian ini dilakukan oleh rendahnya kemampuan siswa di SMA yang dapat disebabkan oleh faktor eksternal dan faktor internal. Faktor eksternal, seperti metode dan strategi pembelajaran. Faktor internal, seperti emosi siswa atau kecemasan terhadap matematika. Penelitian ini hendak mengetahui bagaimana pengaruh kecemasan matematika terhadap keterampilan pemecahan masalah. Penelitian ini dilakukan di SMAN 2 Kota Serang. Metode penelitian ini adalah deskriptif kuantitatif dengan mengambil 3 kelas sebagai sampel. Data dikumpulkan menggunakan kuesioner dan tes. Hasil penelitian ini menunjukkan bahwa 1) rata-rata keterampilan pemecahan masalah matematika siswa adalah siswa yang memiliki kecemasan rendah memiliki skor yang sama dengan siswa yang memiliki kecemasan sedang, dan siswa yang memiliki kecemasan sedang lebih baik daripada siswa yang memiliki kecemasan tinggi, dan siswa yang memiliki kecemasan rendah memiliki skor lebih baik daripada siswa yang memiliki kecemasan tinggi 2) ada hubungan negatif antara kecemasan dan keterampilan pemecahan masalah 3) semakin tinggi tingkat kecemasan, semakin rendah keterampilan pemecahan masalah. Dari hasil tersebut, dapat disimpulkan bahwa ada perbedaan keterampilan pemecahan masalah matematika berdasarkan tingkat kecemasan, ada hubungan antara kecemasan matematika dan keterampilan pemecahan masalah matematika dan ada pengaruh antara kecemasan matematika dan keterampilan pemecahan masalah.
\end{abstract}

Kata kunci: Keterampilan Pemecahan Masalah Matematika, Kecemasan Matematika

\begin{abstract}
This research is conducted by the low ability of students in high school which could be caused by external factors and internal factors. External factors, such as learning methods and strategies. Internal factors, such as student's emotions or anxiety towards mathematics. This study is about to determine how the effect of math anxiety on problem solving skills. This research was conducted at SMAN 2 Kota Serang. The method of this research is quantitative descriptive by making 3 classes as sample. The data were collected using questionnaire and test. The result of this study indicate that 1) the average of student's mathematical problem solving skill is different
\end{abstract}


students with low anxiety have the same score to student with mid anxiety, and students with mid anxiety have a better than student with high anxiety, and students with low anxiety have better score than student with high anxiety 2) there is a negative relationship between anxiety and problem solving skill 3) the higher the anxiety level is, the lower the problem solving skill is. From the result, it can be concluded that there is a difference in mathematical problem solving skill based on the level of anxiety, there is a relationship between mathematical anxiety and mathematical problem solving skill and there is an effect between math anxiety and problem solving skill.

Keywords: Mathematical Problem Solving Skill, Mathematics Anxiety

\section{PENDAHULUAN}

Matematika merupakan elemen penting dalam kehidupan. Bahkan dapat dikatakan bahwa segala kegiatan atau hal-hal yang ada dalam kehidupan kita terjadi berkat kontribusi matematika di dalamnya. Sebut saja kegiatan berhitung, transaksi jual beli, teknologi, sampai kegiatan sederhana seperti melihat jam di pagi hari saat kita bangun dari tidur. Hal ini diperkuat oleh pernyatan yang disebutkan oleh Cockroft (Shadiq, 2007: 1) "It would be very difficult - perhaps impossible - to live a normal life in very many parts of the world in the twentieth century without making use of mathematics of some kind". Artinya, Akan sangat sulit - mungkin mustahil - untuk menjalani kehidupan normal di sangat banyak bagian dunia pada abad kedua puluh tanpa menggunakan matematika. Oleh karena itu, sudah pantaslah matematika menjadi kebutuhan yang harus dipenuhi bagi setiap individu di muka bumi ini.

Melihat pentingnya matematika bagi manusia dalam menjalani kehidupan, maka kompetensi matematika atau ilmu matematika harus dikuasai setiap individu demi meningkatkan kualitas hidupnya, bahkan menjadi acuan berkembangnya suatu negara. Saputra (2014: 75) menyatakan bahwa "matematika merupakan salah satu disiplin ilmu yang sangat berkembang pesat dalam meningkatkan kemajuan suatu negara”. Semakin seorang individu menguasai ilmu matematika maka dirinya dapat berkontribusi lebih baik dalam berbagai aspek demi memajukan negaranya seperti aspek ekonomi, teknologi, pertanian, perikanan, dan lain sebagainya.

Melihat pentingnya matematika, Indonesia pun telah menjadikan matematika sebagai kompetensi wajib yang harus dimiliki setiap warga negaranya. Matematika telah menjadi pelajaran wajib bagi setiap siswa dalam menjalani pendidikan dari jenjang SD hingga SMA sejak beberapa generasi ke belakang hingga sekarang. Matematika juga menjadi pokok utama dalam ujian nasional setiap jenjang pendidikan, bahkan matematika juga menjadi syarat utama untuk melanjutkan pendidikan ke tingkat perkuliahan serta menjadi syarat utama pula pada seleksi dunia kerja.

Di samping itu, Indonesia memiliki tujuan kurikulum tersendiri dalam pembelajaran matematika, salah satunya adalah mengembangkan kemampuan pemecahan masalah. Darminto (2013: 102) mengatakan "kemampuan pemecahan masalah ini sangat penting karena dalam kehidupan sehari-hari setiap manusia selalu berhadapan dengan berbagai masalah yang harus diselesaikan, termasuk 
masalah matematis atau masalah yang solusinya perlu perhitungan matematik". Melalui pembelajaran matematika, seorang siswa diharapkan mempunyai kemampuan memecahkan masalah yang meliputi kemampuan memahami masalah, merancang strategi pemecahan masalah matematika, menyelesaikan model matematika, dan bertanggungjawab atas solusi yang diperoleh.

Pemecahan masalah merupakan fokus dalam pembelajaran matematika. Guna meningkatkan kemampuan pemecahan masalah maka perlu dikembangkan keterampilan memahami masalah, membuat model matematika, menyelesaikan masalah, menafsirkan solusinya (Oktaviyanthi \& Agus, 2018: 3). Di sini lah peran seorang pengajar untuk bisa mengarahkan pembelajarannya pada konteks pemecahan masalah agar siswa terlatih dalam menguasai indikator-indikator pemecahan masalah tersebut.

Berkaca pada kenyataan saat ini, Indonesia menempati peringkat 38 dari 42 negara dengan skor rata-rata 386 pada kategori tingkat kemampuan pemecahan masalah menurut data TIMSS (Trends in Mathematics and Science Study) pada tahun 2011 dan pada tahun 2015 Indonesia menempati peringkat 69 dari 76 negara dengan perolehan rata-rata skor 500. Hasil rendah juga didapat Indonesia pada survai PISA tahun 2015 yang dirilis tanggal 6 Desember 2016, menempatkan Indonesia pada peringkat 63 dari 72 negara. Berdasarkan data tersebut, hendaknya guru dapat memahami bahwa kemampuan pemecahan masalah siswa masih rendah dan dapat menemukan pembelajaran yang dapat mengembangkan kemampuan pemecahan masalah siswa.

Kecemasan merupakan hal yang lumrah yang digambarkan sebagai perasaan tidak nyaman terhadap suatu penyebab kecemasan tersebut. Nawangsari (Saputra, 2014: 77) mengatakan kecemasan adalah "suatu kondisi yang tidak menyenangkan meliputi rasa takut, rasa tegang, khawatir, bingung, tidak suka yang sifatnya subjektif dan timbul karena adanya perasaan tidak aman terhadap bahaya yang akan terjadi". Kecemasan dalam diri siswa dapat terjadi jika siswa sudah mengalami perasaan frustasi yang terus menerus dalam melakukan pembelajaran. Susanto (2016: 136) mengatakan "kecemasan dalam belajar sangat berpengaruh terhadap proses belajar siswa, baik di sekolah, di lingkungan keluarga, maupun di pergaulan". Perasaan cemas tersebut akan mendorong siswa melakukan penghindaran terhadap sumber kecemasan, dalam hal ini sumber salah satunya adalah matematika. Perasaan cemas yang dialami ketika melakukan pembelajaran matematika atau hal-hal yang melibatkan matematika itu lah yang disebut sebagai kecemasan matematika.

Ma (Zakaria \& Nordin, 2007: 27) mendapati bahwa hubungan antara kecemasan matematika dengan prestasi siswa dalam matematika adalah signifikan. Hal ini berarti kecemasan matematika dapat berimbas pada rendahnya prestasi belajar matematika siswa di sekolah.

Pembelajaran yang monoton dan kurang menekankan pada pemecahan masalah mengakibatkan kurangnya kemampuan siswa dalam hal itu yang berdampak pada rasa frustasi siswa kala dihadapkan pada soal pemecahan masalah yang berujung pada rasa cemas. Permasalahan inilah yang mendorong penulis untuk melakukan penelitian tentang sejauh mana kemampuan pemecahan masalah jika ditinjau dari tingkatan kecemasan yang dialami siswa. 


\section{KAJIAN TEORI}

\section{Kecemasan Matematis}

Anditya (2016: 6) mendefinisikan kecemasan matematika adalah "perasaan tertekan, khawatir, cemas, gelisah, tidak suka, maupun rasa takut seseorang terhadap segala sesuatu yang berkaitan dengan matematika". Hal ini dikhawatirkan mempengaruhi kondisi psikologi dan emosi siswa saat melakukan pembelajaran matematika. Haralson (2002) membagi gejala kecemasan matematika menjadi 2 aspek sebagai berikut:

1. Gejala fisik kecemasan matematika yaitu berupa perut mual, tangan dan kaki berkeringat, meningkatnya detak jantung, tidak teratur ketegangan otot, tangan terkepal, bahu ketat, merasa pingsan, sesak napas, sakit kepala, gemetaran, mulut kering, keringat dingin, dan keringat berlebih.

2. Gejala psikologis kecemasan matematika yaitu berupa berpikiran negatif, panik atau takut, khawatir, ketakutan, keinginan untuk melarikan diri atau menghindarinya sama sekali, perasaan tidak berdaya atau ketidakampuan untuk mengatasi persoalan dalam matematika, disorganisasi mental berpikir koheren, perasaan kegagalan atau berharga, ketegangan ekstrim dan gugup, dan ketidakmampuan untuk mengingat materi yang dipelajari.

Ma (Zakaria \& Nordin, 2007: 27) mendapati bahwa hubungan antara kecemasan matematika dengan prestasi siswa dalam matematika adalah signifikan. Hal ini berarti kecemasan matematika dapat berimbas pada rendahnya prestasi belajar matematika siswa di sekolah. Indikator kecemasan matematika siswa pada penelitian ini dirumuskan oleh Suharyadi (Satriyani, 2016), dan akan digunakan sebagai acuan untuk instrumen pengukur kecemasan matematika, sebagai berikut:

Tabel 1. Indikator Kecemasan Matematika Faktor Kecemasan Indikator

\begin{tabular}{ll}
\hline \multicolumn{1}{c}{ Faktor Kecemasan } & \multicolumn{1}{c}{ Indikator } \\
\hline Kognitif (Berpikir) & $\begin{array}{l}\text { Kemampuan diri, Kepercayaan diri, Sulit } \\
\text { konsentrasi, Takut gagal }\end{array}$ \\
Afektif (Sikap) & Gugup, Kurang senang, Gelisah \\
Fisiologis (Reaksi kondisi fisik) & $\begin{array}{l}\text { Rasa mual, Berkeringat dingin, Jantung } \\
\text { berdebar, Sakit kepala }\end{array}$
\end{tabular}

\section{Kemampuan Pemecahan Masalah Matematis}

Lidinillah (Indarwati dkk, 2014: 19) mengatakan bahwa "masalah dalam pembelajaran matematika dapat disajikan dalam bentuk soal tidak rutin yang berupa soal cerita, penggambaran fenomena atau kejadian, ilustrasi gambar atau teka-teki”. Dengan begitu, dapat dikatakan masalah matematika adalah soal matematika yang diberikan kepada siswa dalam bentuk soal tidak rutin dan diselesaikan pula oleh siswa dengan menggunakan algoritma yang tidak rutin.

Adapun dalam penelitian ini, indikator kemampuan pemecahan masalah yang digunakan adalah yang telah dirumuskan di atas secara singkat, yaitu

a. Kemampuan mengidentifikasi masalah

b. Membuat dan merumuskan model matematika yang tepat

c. Memilih strategi pemecahan masalah yang terbaik 
d. Bertanggungjawab atas kebenaran jawaban yang diperoleh melalui proses yang telah dilakukan.

\section{METODE}

Penelitian ini merupakan penelitian deskriptif kauntitatif dengan metode survei yang bermaksud mencari seberapa besar pengaruh antar variabel. Variabelvariabel yang dimaksud adalah variabel bebas $(X)=$ Tingkat kecemasan matematika dan variabel terikat $(\mathrm{Y})=$ Kemampuan pemecahan masalah.

Penelitian dilakukan di SMAN 2 Kota Serang dengan mengambil sampel berjumlah 3 kelas. Pengambilan data tingkat dilakukan menggunakan angket uji kecemasan siswa yang kemudian hasilnya dibagi menjadi 3 yakni siswa berkecemasan tinggi, siswa berkecemasan sedang, dan siswa siswa berkecemasan rendah. Untuk menafsirkan penggolongan tingkat kecemasan digunakan persentase dari skala Likert sebagai berikut:

Tabel 2. Kriteria Tingkat Kecemasan Matematika

\begin{tabular}{cc}
\hline Persentase Skor & Tingkat Kecemasan Matematika \\
\hline $25 \% \leq \mathrm{P} \leq 50 \%$ & Rendah \\
$50 \%<\mathrm{P} \leq 75 \%$ & Sedang \\
$75 \%<\mathrm{P} \leq 100 \%$ & Tinggi \\
\hline
\end{tabular}

Kuesioner terdiri dari empat alternatif pilihan jawaban, yaitu SS (Sangat Setuju), S (Setuju), TS (Tidak Setuju), STS (Sangat Tidak Setuju). Adapun penyusunan kuesioner menyesuaikan pada indikator kecemasan matematika yang dirumuskan Suharyadi (Satriyani, 2016).

Sedangkan pengambilan data kemampuan pemecahan masalah dengan menggunakan tes kemampuan pemecahan masalah matematika yang terdiri dari 5 soal dimana setiap soal dilihat keempat indikator kemampuan pemecahan masalah. Skor kemampuan pemecahan masalah matematika akan diukur dengan menggunakan rubrik holistik. Rubrik holistik adalah pedoman untuk menilai berdasarkan kesan keseluruhan atau kombinasi semua kriteria (Iriyanti, 2004). Soal tes dilakukan uji instrumen terlebih dahulu dengan hasilnya valid dan reliabel sehingga dapat digunakan untuk melihat kemampuan pemecahan masalah siswa.

Kemudian, pertama data diolah menggunakan uji ANOVA satu jalur untuk melihat adakah perbedaan rata-rata kemampuan pemecahan masalah siswa antara siswa berkecemasan tinggi, sedang, dan rendah. Analisis data kedua yakni uji korelasi untuk melihat adakah hubungan antara tingkat kecemasan dengan kemampuan pemecahan masalah. Analisis data ketiga yaitu uji regresi untuk melihat bagaimana pengaruh tingkat kecemasan terhadap kemampuan pemecahan masalah siswa.

\section{HASIL DAN PEMBAHASAN \\ Hasil}

\section{Perbedaan Rata-Rata Kemampuan Pemecahan Masalah Siswa Berdasarkan Tingkat Kecemasan}

Perbedaan rata-rata kemampuan pemecahan masalah matematika dari masing-masing kelompok dapat diketahui dengan statistik uji-F. Adapun untuk mempermudah maka akan disajikan tabel perhitungan berikut: 
Tabel 2. ANOVA Satu Jalur

\begin{tabular}{cccccc}
\hline Sumber Variansi & df & Jk & Rk & $\mathrm{F}_{\text {hitung }}$ & $\mathrm{F}_{\text {tabel }}$ \\
\hline Antar Kelompok & 2 & 2901,78 & 1450,89 & 22,74 & 3,09 \\
Dalam Kelompok & 94 & 5995,69 & 63,78 & & \\
Total & 96 & 8897,48 & & & \\
\hline
\end{tabular}

Berdasarkan tabel di atas didapat $\mathrm{F}_{\text {hitung }}=22,74>\mathrm{F}_{\text {tabel }}=3,09$ maka $\mathrm{H}_{0}$ ditolak, artinya terdapat perbedaan rata-rata kemampuan pemecahan masalah matematika ditinjau dari kecemasan tingkat kecemasan matematika. Untuk mengetahui perbedaan tiap tingkatan secara signifikan akan dilakukan uji lanjutan t-Dunnet. Berikut tabel perhitungannya:

Tabel 3. Perhitungan Uji Lanjutan t-Dunnet $(\alpha=\mathbf{0 , 0 5})$

\begin{tabular}{ccccc}
\hline Perbandingan & Nilai Kontras & $\mathrm{t}_{\text {hitung }}$ & $\mathrm{t}_{\text {tabel }}$ & Interpretasi \\
\hline $\mathrm{A}_{1} \& \mathrm{~A}_{2}$ & 3,08 & 1,61 & 1,66 & Tidak Signifikan \\
$\mathrm{A}_{2} \& \mathrm{~A}_{3}$ & 11,09 & 5,47 & 1,66 & Signifikan \\
$\mathrm{A}_{1} \& \mathrm{~A}_{3}$ & 14,16 & 6,42 & 1,66 & Signifikan \\
\hline
\end{tabular}

Berdasarkan tabel di atas maka data dapat dianalisis sebagai berikut:

a. Terdapat perbedaan yang tidak signifikan atau cenderung sama pada kemampuan pemecahan masalah matematika siswa berkecemasan rendah $\left(A_{1}\right)$ dengan siswa berkecemasan sedang $\left(\mathrm{A}_{2}\right)$

$$
\begin{aligned}
& \mathrm{H}_{0}: \mu_{1}=\mu_{2} \\
& \mathrm{H}_{1}: \mu_{1} \neq \mu_{2}
\end{aligned}
$$

Dari tabel dapat dilihat bahwa $\mathrm{t}_{\text {hitung }}=1,610<\mathrm{t}_{\text {tabel }}=1,661$, maka $\mathrm{H}_{0}$ diterima, sehingga tidak terdapat perbedaan kemampuan pemecahan masalah siswa berkecemasan rendah dan kemampuan pemecahan masalah siswa berkecemasan sedang.

b. Terdapat perbedaan yang signifikan pada kemampuan pemecahan masalah siswa berkecemasan sedang $\left(A_{2}\right)$ dengan siswa berkecemasan tinggi $\left(A_{3}\right)$

$$
\begin{aligned}
& \mathrm{H}_{0}: \mu_{2}=\mu_{3} \\
& \mathrm{H}_{1}: \mu_{2} \neq \mu_{3}
\end{aligned}
$$

Dari tabel dapat dilihat bahwa $t_{\text {hitung }}=5,471>t_{\text {tabel }}=1,661$, maka tolak $\mathrm{H}_{0}$, sehingga secara signifikan kemampuan pemecahan masalah siswa berkecemasan sedang lebih baik dibanding siswa berkecemasan tinggi.

c. Terdapat perbedaan yang pada kemampuan pemecahan masalah siswa berkecemasan rendah $\left(A_{1}\right)$ dengan siswa berkecemasan tinggi $\left(A_{3}\right)$

$$
\begin{aligned}
& \mathrm{H}_{0}: \mu_{1}=\mu_{3} \\
& \mathrm{H}_{1}: \mu_{1} \neq \mu_{3}
\end{aligned}
$$

Dari tabel dapat dilihat bahwa $\mathrm{t}_{\text {hitung }}=6,426>\mathrm{t}_{\text {tabel }}=1,661$, maka tolak $\mathrm{H}_{0}$, sehingga secara signifikan kemampuan pemecahan masalah siswa berkecemasan rendah lebih baik dibanding siswa berkecemasan tinggi. 


\section{Hubungan Antara Tingkat Kecemasan Siswa dengan Kemampuan Pemecahan Masalah Siswa}

Untuk mencari hubungan dan membuktikan hipotesis hubungan antara kemampuan pemecahan masalah matematika dengan kecemasan matematika dapat digunakan analisis korelasi product moment. Adapun untuk mempermudah maka disajikan tabel perhitungan berikut:

Tabel 3. Korelasi Product Moment

\begin{tabular}{ccccc}
\hline $\mathrm{X}$ & $\mathrm{Y}$ & $\mathrm{r}_{\text {hitung }}$ & $\mathrm{r}_{\text {tabel }}$ & Keterangan \\
\hline $\begin{array}{c}\text { Kecemasan } \\
\text { Matematika }\end{array}$ & $\mathrm{KPMM}$ & $-0,565$ & 0,168 & Sedang \\
\hline
\end{tabular}

Dari perhitungan yang dilakukan didapatkan $r_{\text {hitung }}=0,565>r_{\text {tabel }}=0,168$, maka $\mathrm{H}_{0}$ ditolak, sehingga terdapat hubungan antara kemampuan pemecahan masalah matematika dengan kecemasan matematika dan tanda negatif menunjukkan arah hubungan yang negatif.

Dengan besaran nilai koefisien determinasi adalah

$$
\text { KD } \quad \begin{aligned}
& r^{2} \times 100 \% \\
& =-0,565^{2} \times 100 \% \\
& =0,319
\end{aligned}
$$

Yang berarti besaran pengaruh variabel bebas terhadap variabel terikat sebesar 0,319 dan sisanya dipengaruhi oleh faktor-faktor lain.

\section{Pengaruh Antara Tingkat Kecemasan Terhadap Kemampuan Pemecahan Siswa}

Untuk mengetahui apakah terdapat pengaruh antara tingkat kecemasan matematika dengan kemampuan pemecahan masalah matematika dan juga untuk membuat keputusan apakah naik atau menurunnya variabel dependen dapat dilakukan melalui peningkatan variabel independen atau tidak menggunakan analisis regresi dengan pengambilan keputusan sebagai berikut:

a. Jika koefisien dari variabel bebas (X) bertanda positif, maka hubungan antarvariabel memiliki hubungan yang positif.

b. Jika koefisien dari variabel bebas (X) bertanda negatif, maka hubungan antarvariabel memiliki hubungan yang negatif.

1) Adapun perhitungan harga a dan b sebagai berikut:

$$
\begin{aligned}
\mathrm{a} & =\frac{\sum Y \sum X^{2}-\sum X \sum X Y}{n \sum X^{2}-\left(\sum X\right)^{2}} \\
& =\frac{(3368)(706,331)-(255,749)(8578,3953)}{97(706,331)-255,749^{2}} \\
& =59,55 \\
\mathrm{~b} & =\frac{n \sum X Y-\sum X \sum Y}{n \sum X^{2}-\left(\sum X\right)^{2}} \\
& =\frac{97(8587,3953)-(255,749)(3368)}{97(706,331)-255,749^{2}} \\
& =-9,42
\end{aligned}
$$

2) Sehingga persamaan regresi menjadi

$$
Y=59,55-9,42 X
$$

Yang berarti hubungan antar variabel memiliki hubungan yang negatif.

3) Untuk mempermudah maka hasil uji keberartian regresi disajikan dalam tabel berikut: 
Tabel 4. Uji Keberartian Regresi

\begin{tabular}{llllll}
\hline \multicolumn{1}{c}{ Sumber Variasi } & \multicolumn{1}{c}{ Dk } & \multicolumn{1}{c}{ JK } & \multicolumn{1}{c}{ KT } & Fhitung & Ftabel \\
\hline Total & 97 & 125840 & - & & \\
Koefisien (a) & 1 & 116942,52 & 116942,52 & & \\
Regresi (b/a) & 1 & 2840,83 & 2840,83 & 44,56 & 3,09 \\
Sisa & 95 & 6056,65 & 63,75 & & \\
\hline
\end{tabular}

$\mathrm{H}_{0}$ : Regresi tidak berarti

$\mathrm{H}_{1}$ : Regresi berarti

Berdasarkan tabel di atas maka data dapat dianalisis sebagai berikut:

$\mathrm{F}_{\text {hitung }}=44,56>\mathrm{F}_{\text {tabel }}=3,09$ maka $\mathrm{H}_{0}$ ditolak, sehingga regresi berarti atau $\mathrm{b} \neq 0$.

\section{Pembahasan}

Hasil penelitian menunjukkan bahwa kemampuan pemecahan masalah siswa yang berkecemasan rendah cenderung sama dibanding siswa yang berkecemasan sedang tetapi lebih tinggi jika dibandingkan dengan siswa yang berkecemasan tinggi begitu juga siswa berkecemasan sedang memiliki kemampuan pemecahan masalah lebih tinggi dibanding siswa berkecemasan tinggi. Hasil penelitian ini sejalan dengan pengamatan peneliti saat pengambilan data pemecahan masalah, seperti raut wajah tegang dan berkomentar bahwa soal tes yang diberikan sukar, meski belum melihat secara keseluruhan tes yang diberikan. Saat proses pengerjaan soal berlangsung banyak siswa yang menarik nafas, memijit-mijit kening, memberikan tatapan lelah, mengeluh, mengerutkan kening, mondar-mandir ke toilet dan mencoret-coret kertas tetapi bukan merupakan solusi dari tes yang diberikan. Hal ini sesuai dengan gejala-gejala kecemasan yang disebutkan Haralson (2002) yang membagi gejala kecemasan menjadi 2, yaitu gejala fisik seperti kelelahan, sakit kepala, mulut kering, keringat dingin, keringat berlebih dan lain lain serta gejala psikologis seperti panik atau takut, khawatir, keinginan untuk melarikan diri atau menghindarinya sama sekali, ketidakmampuan mengingat materi yang dipelajar dan lain lain.

Setelah melakukan pengecekan terhadap hasil tes keseluruhan siswa, didapat siswa yang menunjukkan sikap tenang dan berkonsentrasi memperoleh skor lebih baik dibanding siswa yang menunjukkan reaksi kecemasan tinggi. Dimana untuk sebagian besar siswa yang berkecemasan tinggi jarang menyelesaikan soal secara keseluruhan dan banyak tidak tepat dalam mengidentifikasi soal tes yang diberikan sehingga berimbas terhadap hasil akhir. Untuk siswa yang berkecemasan sedang, sebagian siswa dapat menjawab soal secara keseluruhan dan tepat sedangkan sebagian lain tidak dapat menjawab soal secara keseluruhan. Untuk sebagian besar siswa yang berkecemasan rendah cenderung mengerjakan soal secara keseluruhan dan mendapatkan poin mendekati maksimal atau maksimal di tiap nomor yang dikerjakan. Faktor lain seperti kurangnya waktu atau pemahaman konsep juga mempengaruhi jawaban siswa secara keseluruhan dari tiga kelompok kecemasan sehingga ada poin poin soal yang tidak dikerjakan atau bahkan 1 soal tidak dikerjakan sama sekali.

Berikut ini akan disajikan contoh penyelesaian dari soal tes nomor 1 masing-masing siswa dengan tingkat kecemasan berbeda: 
1. Seorang anak mengamati seorang bapak sedang lari pagi mengitari kolam air mancur yang berbentuk lingkaran dengan jarak lintasan bapak ke pusat kolam adalah 5m, sedangkan jarak anak terhadap pusat kolam adalah $10 \mathrm{~m}$. Jika diasumsikan posisi tempat anak melihat dinyatakan sebagai titik pangkal koordinat kartesius dalam meter dan pusat lingkaran terdapat pada sumbu x

a. Tulislah elemen-elemen yang diketahui dari masalah tersebut dan gambarkan kondisi tersebut ke dalam diagram Kartesius

b. Tulislah rumus persamaan umum lingkaran yang memenuhi kondisi tersebut

c. Temukan persamaan lingkaran menggunakan rumus terbaik yang telah Anda tuliskan

d. Gunakan 1 titik sembarang pada lingkaran untuk membuktikan persamaan lingkaran yang telah dibuat benar

Berikut adalah contoh penyelesaian dari salah satu siswa berkecemasan tinggi, sedang, dan rendah:

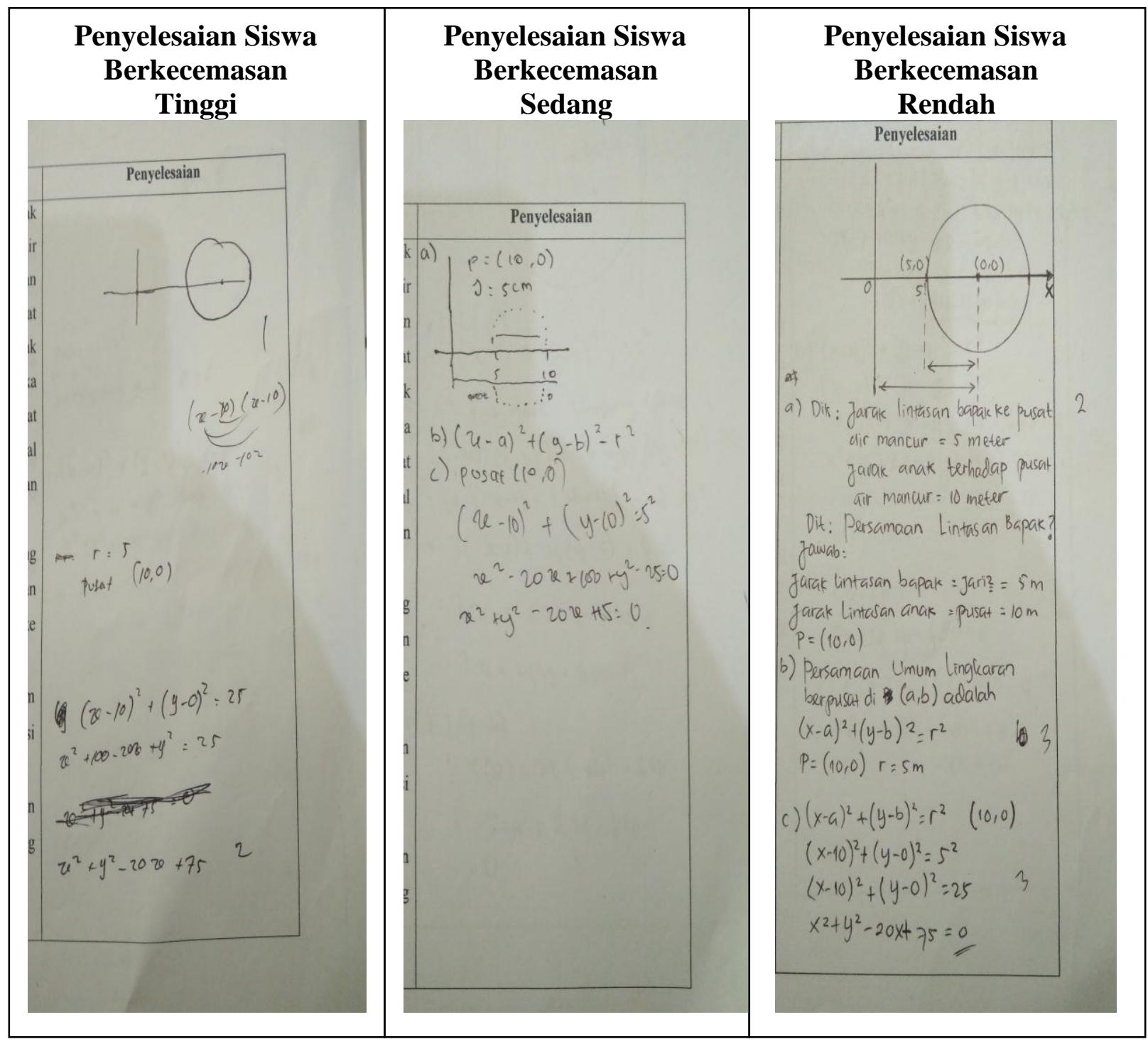

Gambar 1. Penyelesaian Tes KPMM Berdasarkan Tingkat Kecemasan 
Berdasarkan gambar tersebut, dapat dilihat bahwa pada indikator pertama kemampuan pemecahan masalah yaitu menunjukan pemahaman masalah, siswa dengan tingkat kecemasan tinggi cenderung tidak sempurna dalam menginterpretasikan soal ke dalam bentuk gambar dan juga tidak bisa menuliskan unsur-unsur diketahui dan ditanyakan dari masalah yang diberikan. Untuk siswa dengan tingkat kecemasan sedang, siswa sudah bisa menginterpretasikan soal ke dalam bentuk gambar meskipun belum sempurna dimana seharusnya lintasan lari bapak berbentuk lingkaran meskipun juga tidak menuliskan dengan jelas elemenelemen diketahui dan ditanyakannya. Sedangkan pada siswa dengan tingkat kecemasan rendah, dapat dilihat bahwa siswa sudah dengan sangat baik menginterpretasikan soal ke dalam bentuk gambar dan juga elemen-elemen diketahui dan ditanyakan dari masalah dituliskan dengan lengkap.

Pada indikator kedua kemampuan pemecahan masalah yaitu menyusun model matematika, siswa dengan tingkat kecemasan tinggi salah menginterpretasikan soal dimana seharusnya yang dituliskan adalah persamaan umumnya bukan persamaan lingkaran yang seharusnya itu merupakan jawaban untuk poin ketiga. Untuk siswa dengan tingkat kecemasan sedang, siswa sudah bisa menuliskan persamaan umum lingkaran yang diinginkan berdasarkan gambar. Siswa dengan tingkat kecemasan rendah dapat membuat model atau persamaan umum lingkaran sesuai dengan prosedur dan mengarah pada solusi yang benar.

Indikator kemampuan pemecahan masalah berikutnya yaitu melaksanakan pemecahan masalah. Pada jawaban siswa dengan tingkat kecemasan tinggi, siswa salah dalam menuliskan solusi yang diiinginkan, serta tidak melakukan penjabaran yang rapi. Pada jawaban siswa dengan tingkat kecemasan sedang, meskipun belum dijabarkan dengan rapi tetapi solusi yang dituliskan benar dan sesuai. Jawaban pada siswa dengan tingkat kecemasan rendah, benar dan sesuai serta dapat menjabarkan dengan rapi yang mencerminkan sikap tenang dalam pengerjaan soal.

Pada indikator terakhir kemampuan pemecahan masalah yaitu pemeriksaan kembali, siswa dengan tingkat kecemasan tinggi tidak melaksanakan kegiatan tersebut. Siswa dengan tingkat kecemasan sedang sudah melakukan pemeriksaan pada jawaban yang diberikan. Begitu juga dengan siswa dengan tingkat kecemasan rendah, sudah dapat melakukan pemeriksaan jawaban dengan baik.

Berdasarkan analisis data, hasil menunjukkan bahwa skor rata-rata kemampuan pemecahan masalah matematika siswa berkecemasan tinggi sebesar 25,46, siswa berkecemasan sedang sebesar 36,55, dan siswa berkecemasan rendah sebesar 39,62. Uji lanjut dengan uji t-Dunnet pada taraf signifikansi 5\% didapat $\mathrm{t}_{\text {hitung }}=1,610<\mathrm{t}_{\text {tabel }}=1,661$ pada perbandingan antara kemampuan pemecahan masalah siswa berkecemasan rendah dengan siswa berkecemasan sedang, yang artinya dengan tingkat kepercayaan 95\% tidak terdapat perbedaan kemampuan pemecahan masalah siswa berkecemasan rendah dan siswa berkecemasan sedang cenderung sama. Pada perbandingan kemampuan pemecahan masalah siswa berkecemasan sedang dengan siswa berkecemasan tinggi, didapat $t_{\text {hitung }}=5,471>$ $\mathrm{t}_{\text {tabel }}=1,661$, yang artinya dengan tingkat kepercayaan 95\% kemampuan pemecahan masalah siswa berkecemasan sedang lebih baik dibanding siswa berkecemasan tinggi. Pada perbandingan kemampuan pemecahan masalah siswa 
berkecemasan rendah dengan siswa berkecemasan tinggi didapat $\mathrm{t}_{\text {hitung }}=6,426>$ $\mathrm{t}_{\text {tabel }}=1,661$, yang artinya dengan tingkat kepercayaan 95\% kemampuan pemecahan masalah siswa berkecemasan rendah lebih baik dibanding siswa berkecemasan tinggi.

Penelitian memberikan nilai hasil korelasi antara tingkat kecemasan matematika dengan kemampuan pemecahan masalah matematika sebesar $r_{\text {hitung }}=$ $0,565>\mathrm{r}_{\text {tabel }}=0,168$ dengan $\mathrm{dk}=97$ dan taraf signifikansi $5 \%$, artinya terdapat hubungan antara tingkat kecemasan matematika dengan kemampuan pemecahan masalah matematika. Tanda negatif menunjukkan hubungan negatif antara tingkat kecemasan dengan kemampuan pemecahan masalah matematika.

Namun pada penelitian ini terdapat anomali dimana terdapat 1 siswa dengan tingkat kecemasan rendah mendapatkan skor kemampuan pemecahan masalah yang buruk. Hal ini terjadi karena kurangnya pemahaman siswa terhadap materi soal yang diberikan, dapat dilihat melalui gejala-gejala kecemasan yang tidak terdapat pada siswa tersebut dan juga soal-soal dikerjakan secara menyeluruh tetapi solusi yang diberikan tidak sesuai dengan yang diinginkan. Pendapat ini didasari pernyataan Purwanto (2009) yang mengatakan bahwa pemahaman adalah tingkat kemampuan yang mengharapkan responden mampu memahami arti atau konsep, situasi serta fakta yang diketahuinya. Sehingga, jika siswa tidak memiliki pemahaman terhadap suatu konteks masalah maka siswa tidak dapat memahami arti atau konsep dari masalah tersebut, yang berakibat pada tidak mampunya memecahkan atau menemukan solusi dari masalah.

Dari hasil analisis regresi yang dilakukan, penelitian menghasilkan nilai konstanta a sebesar 59,55 dan koefisien dari variabel $X$ atau b adalah $-9,42$ yang bertanda negatif yang berarti hubungan antar variabel bernilai negatif. Besar persentase pengaruh tingat kecemasan matematika terhadap kemampuan pemecahan masaah matematika adalah 0,319 atau 31,9\% dan sisanya dipengaruhi oleh variabel-variabel lain.

Jika dituliskan, persamaan regresi menjadi $Y=59,55-9,42 X$. Yang artinya semakin tinggi tingkat kecemasan matematika maka akan semakin rendah kemampuan pemecahan masalah matematikanya. Temuan ini relevan dengan penelitian yang dilakukan Siswono (2008), hasil penelitian menunjukkan bahwa kecemasan berpengaruh signifikan dengan kemampuan pemecahan masalah, dimana dalam penelitiannya pengaruh kecemasan terhadap kemampuan pemecahan masalah sebesar $27,38 \%$.

\section{SIMPULAN DAN SARAN}

\section{Simpulan}

Berdasarkan temuan dan pembahasan hasil penelitian, diperoleh kesimpulan penelitian yaitu terdapat perbedaan kemampuan pemecahan masalah matematika siswa berdasarkan tingkatan kecemasan. Rata-rata kemampuan pemecahan masalah matematika siswa berkecemasan rendah cenderung sama dibanding siswa berkecemasan sedang. Rata-rata kemampuan pemecahan masalah matematika siswa berkecemasan rendah lebih baik jika dibandingkan siswa berkecemasan tinggi. Rata-rata kemampuan pemecahan masalah matematika siswa berkecemasan sedang lebih baik jika dibandingkan dengan kemampuan pemecahan masalah matematika berkecemasan tinggi.

Kemudian terdapat hubungan yang signifikan antara tingkat kecemasan 
matematika dengan kemampuan pemecahan masalah matematika. Besar hubungan tingkat kecemasan matematika dengan kemampuan pemecahan masalah matematika adalah sebesar -0,565. Tanda negatif menunjukan hubungan negatif antara tingkat kecemasan matematika dengann kemampuan pemecahan masalah matematika, yang artinya semakin tinggi tingkat kecemasan siswa maka semakin rendah kemampuan pemecahan masalahnya.

Selanjutnya, ada pengaruh signifikan antara tingkat kecemasan matematika dengan kemampuan pemecahan masalah matematika. Besar persentase pengaruh tingkat kecemasan matematika terhadap kemampuan pemecahan masalah matematika adalah $31,9 \%$ dan sisanya dipengaruhi oleh variabel-variabel lain.

\section{Saran}

Berdasarkan pembahasan dan kesimpulan penelitian, hal yang dapat disarankan yaitu para pendidik, khususnya pendidik bidang studi matematika untuk lebih memperhatikan proses pembelajaran baik itu materi, metode pembelajaran, strategi pembelajaran, lingkungan pembelajaran dan lain sebagainya agar lebih menarik dan menyenangkan, sehingga peserta didik tidak merasa tertekan atau mengalami kecemasan yang berlebihan terhadap matematika.

Lalu, kepada para pendidik untuk lebih memperhatikan hal-hal yang mengakibatkan kesenjangan nilai yang terdapat pada peserta didik seperti mengkondisikan kelas, menggunakan bahan ajar, penekanan konsep materi terhadap siswa secara menyeluruh, menerapkan strategi dan metode pembelajaran yang lebih bersahabat dan menarik perhatian peserta didik secara menyeluruh. Selain itu, guru hendaknya membiasakan siswa dalam menyelesaikan soal-soal kemampuan pemecahan masalah matematika.

\section{DAFTAR RUJUKAN}

Anditya, R. (2016). Faktor-Faktor Penyebab Kecemasan Matematika. Artikel Publikasi Ilmiah. Surakarta: UMS

Darminto, B.P. (2013). Meningkatkan Kemampuan Pemecahan Masalah Matematis Mahasiswa Melalui Pembelajaran Model Treffinger. Jurnal Pendidikan Matematika dan Sains Tahun I, 2, 101-107.

Haralson, K. (2002). Math Anxiety: Myth or Monster?. https://www.google.com/url?q=http://www.apsu.edu/sites/apsu.edu/files/har alsonk/anxiety_presentationpaducah.ppt\&sa=U\&ved=0ahUKEwjb_9SXnYf RAhXEt48KHfeHCXgQFggEMAA\&client=internal-udscse\&usg=AF QjCNG195SWzfmBo2GBk1BtfE57qV8Iw (diakses 20 Januari 2018).

Indarwati, D., Wahyudin, \& Novisita, R. (2014). Peningkatan Kemampuan Pemecahan Masalah Matematika Melalui Penerapan Problem Base Learning untuk Siswa Kelas V SD. Satya Widya, 3 (1), 17-27.

Iriyanti, P. (2004). Penilaian Untuk Kerja. Yogyakarta: PPPGM.

Oktaviyanthi, R. \& Agus, R.N. (2018). Peningkatan Kemampuan Pemecahan Masalah Mahasiswa Calon Guru Melalui Keterampilan Fungsional Matematis. Beta: Jurnal Tadris Matematika, 11 (1), 1-19.

Purwanto, N. (2009). Prinsip-prinsip dan Teknik Evaluasi Pengajaran. Bandung: PT Remaja Rosdakarya.

Saputra, P. R. (2014). Kecemasan Matematika dan Cara Menguranginya. Jurnal 
PHYTAGORAS, 3 (2), 75-84.

Satriyani. (2016). Pengaruh Kecemasan Matematika (Mathematics Anxiety) dan Gender Terhadap Kemampuan Pemecahan Masalah Matematis Siswa. Program Sarjana Pendidikan Matematika. Jakarta: UIN

Shadiq, F. (2007). Apa dan Mengapa Matematika Begitu Penting. Yogyakarta: Widyaiswara PPPPTK Matematika

Siswono, T. Y. E. (2008). Model Pembelajaran Matematika Berbasis Pengajuan dan Pemecahan Masalah Untuk Meningkatkan Kemampuan Berpikir Kreatif. Surabaya: Unesa University.

Susanto, H, P. (2016). Analisis Hubungan Kecemasan, Aktivitas, dan Motivasi Berprestasi dengan Hasil Belajar Matematika Siswa. Jurnal Beta, 9 (2), 134-137.

Zakaria, E. \& Norazah, M.N. (2008). The Effect of Mathematics Anxiety on Matriculation Student as Related to Motivation and Achievement. Eurasia Journal of Mathematics, Science, \& Technology Eductation, 4 (1), 27-30 